\title{
Student Satisfaction and Continuance Model of Enterprise Resource Planning (ERP) System Usage
}

\author{
https://doi.org/10.3991/ijet.v14i01.8656 \\ Weli \\ Universitas Katolik Indonesia Atma Jaya, Jakarta, Indonesia \\ weli.imbiri@gmail.com
}

\begin{abstract}
The rapid growth through the use of Enterprise Resource Planning (ERP) systems by Indonesian companies has been responded by ERP vendors in providing skilled human resources in ERP environment by cooperating with universities. SAP as one of the ERP vendors has also cooperated with Atma Jaya Catholic University of Indonesia Jakarta, particularly for accounting students, training is conducted since 2013. This study will test the satisfaction model for the students after they complete the ERP training using the Technology Acceptance Model (TAM) and Continuance Model framework. This research is an explorative study that examines student satisfaction models in using ERP system. The Technology Acceptance Model and Expectation Continuance Model used to build a proposed model. Data collection was done by distributing questionnaires to 319 trainees at the end of the session. The result of analysis using Partial Least Square SEM method shows that confirmation variable, perceived ease of use, satisfaction with class, and satisfaction with an instructor have affected student satisfaction in using ERP system. Furthermore, satisfaction with class and instructor influence perceived ease of use, and, finally, students 'satisfaction effect on students' intention to keep using. Based on the analysis results can be concluded that students feel satisfied with ERP training and this affects their intentions in using ERP in the future.
\end{abstract}

Keywords-ERP training, student satisfaction, continuance model

\section{$1 \quad$ Introduction}

The Enterprise Resource Planning (ERP) system is one of the commercial software packages that have an ability to integrate all business functions and company's resources. ERP has been widely applied in the business, including in Indonesia. As it has been reported by Indonesia Finance Today (http://www.ift.co.id/), ERP consumption value in Indonesia in 2014 reached US\$ 110 million and will increase to US\$ 120 million in 2015. Of course, this figure will be increased in subsequent years, since more and more companies require software to meet the demands of business operations based on information technology, efficiency, productivity, competition, and market demands. 
The growth through the use of ERP in Indonesia gives an indication about the direction of the growing need for skilled labor in using ERP. As the results from previous studies illustrate that the rapid use of IT in the industry in addition to the impact on reducing labor, but also will generate new demand for skilled labor [23], [8]. So, the next question that arises from the phenomenon is whether there are adequate human resources available to respond to the request. Therefore, the increasing demand for skilled labor is an opportunity for universities to prepare graduates that understand and master the concepts of business processes on the ERP environment [4], [27], [24], [10], [5], [22], [12], [13]. Thus, the universities need to prepare their curriculum by adopting the ERP material in lectures.

The ERP learning process can be conducted in different ways ranging from the use of simulation, a subject of its own, some courses that include topics related to ERP modules, or through courses outside compulsory subjects and certification programs [31],[14], [11],[5], [12], [13]. However, there are several ways that can be done when there is cooperation between universities and ERP vendors. One of ERP vendors that do such cooperation is the SAP. As reported on the Economic News dated February 28,2015 , since 2010, SAP, as one of ERP vendors, has trained more than 7000 students in Indonesia. The purpose of the training is to improve the quality of the university graduates, especially in mastering business processes if they choose to work in the ERP environment. The SAP training generally focuses on the participants' understanding of the best practices that existed within the company.

The cooperation programs between SAP and universities have been implemented in more than 510 universities in 37 countries, including Indonesia. Approximately 140,000 students enroll in training programs each year. One of the few universities in Jakarta, who has worked with SAP, is the Atma Jaya Catholic University of Indonesia, Jakarta. However, the implementation of the training in the Faculty of Economics begins in 2013. Because ERP training and the use of ERP applications are a new experience for students, it is, interesting to know the attitude of students after attending SAP Training in Atma Jaya. Therefore, this study was conducted to analyze students' accounting satisfaction with SAP training. The theory to be used is the confirmation and continuance theory proposed by [28]. This model is a modification of the theory of technology acceptance model and the expectation-confirmation theory and continuation of IT usage. In addition, this study also analyzed student satisfaction with course and instructor activities [16].

This study differs from previous studies that describe the learning process of ERP in universities. Many of these studies discussed the learning process that integrates ERP topics in the curriculum [15], [25], [30]. Another topic is discussing how to make use of limited resources given the considerable investment out of ERP [18]. This study specifically proposes the user satisfaction model of ERP user accounting after completing their SAP training. Given that SAP training is a separate activity not related to a particular class or subject, it is also necessary to analyze whether they are satisfied with the use of SAP, and how likely they will use SAP after they graduate from college. Although some previous studies regarding the use of SAP by students have been done, but this study emphasizes on how students' satisfaction in using SAP. Similarly, given the rapid growth of ERP use in the workplace, there is a need to 
investigate whether students are willing to continue using SAP in the workplace. In other words, will students be interested in finding work related to SAP? Based on this idea, the present research adopts the technology acceptance model and the expectancy-continuance theory, which will examine the factors that affect student satisfaction from using ERP, whether the current conditions of training affect their satisfaction from using ERP. Furthermore, whether perceptions of ease of use and perceived usefulness contribute to the satisfaction with ERP usage. Finally, it will be analyzed whether the satisfaction with ERP will affect their intention to keep using ERP in the future.

The results of this study contribute to the field of information systems research in terms of measuring system user satisfaction is associated with training activities to potential end users. As the result of previous research on the role of training in enduser acceptance, the training conditions also support the satisfaction of users of information systems.

\section{Literature Review}

The ERP software usage in the university curriculum has provided an opportunity to conduct research related to the use of ERP by students. The results from previous surveys regarding SAP lessons showed that most of the students were satisfied with the SAP material given in the lecture. That is, the students acknowledged the benefits of the materials presented, especially those related to business processes [21], [12].

The study related to the students' satisfaction from SAP usage was conducted by [9]. He applied factors such as perceived ease of use, perceived usefulness, and computer anxiety to measure users 'satisfaction based on the Technology Acceptance Model (TAM). In addition, he also used a model based on the Expectation Confirmation Theory (ECT), where the confirmation variable was utilized to measure the intentions of the students in using the ERP system in the future. The results from his study confirmed that only perceived ease of use and perceived usefulness was the factors that determine users' satisfaction, and the users' satisfaction influenced the students' intention to use ERP in the future.

Another research that tested the SAP users' satisfaction using TAM is studied by [17]. He added factors of flexibility, commitment, and satisfaction with the instructor. The results from his study gave the confirmation of all variables proposed, but the most powerful variable in explaining the web-based SAP class satisfaction was the satisfaction with the instructor. It should be noted, however, that there are also other studies that do not confirm the influence of perceived usefulness in the users' acceptance of ERP systems [20], [1].

Based on previous research, this research will propose a model of user satisfaction with ERP system to a student by combining the Technology Acceptance Model (TAM) and the Expectation Confirmation Theory (ECT). Considering the training undertaken on students is a proxy for prospective skilled labor, in addition to the characteristics of ERP applications such as ease of use and usability perceptions, then the classroom-training situation is believed to have an impact on user satisfaction 
perceptions and usability intentions. The situation at the time of the training represented by the facilities in the classroom or the way of delivery by the instructor will definitely impact the trainee. Therefore, both TAM and ECT models will be applied as the underlying theories of this research. Both theories are used to test the level of user acceptance and user satisfaction, and to analyze the user's perception of the decision to utilize the system in the future. ECT is applied under the assumption that user perceptions are important once they have experience using the system.

Thus, ECT is relevant in measuring user satisfaction [20], [28]. As previous researchers suggested that there are factors that affect user satisfaction such as perception of ease of use, usability perception [9], [17], confirmation [28], hence, these variables will be used in this study. In addition, student satisfaction from the use of SAP according to [16] can be distinguished between their satisfaction with SAP classes and instructors. Therefore, this study also examines the relationship between satisfaction in SAP classes and instructors with student satisfaction in using SAP after completing the course. Additionally, the dependent variable for this model is the user's intention to use SAP in the future.

Based on the Technology Acceptance Model [6] and the Expectation Confirmation Theory [3], the model of this study examined the effect of variable Confirmation, Satisfaction with Class, and Satisfaction with Instructor, Perceived Ease of Use, and Perceived Usefulness of the User Satisfaction after the SAP course. Previous literature shows that both TAM and ECT has been widely used in research within the field of information systems. The results show that both models are relevant to measuring user satisfaction system through the use of various IT applications [28].

Confirmation variables were originally used in the field of consumer behavior studies that measured individual attitudes to decide on repeat purchase after using the product. The decision to buy back may occur because there is an expectation before using the product, then confirmed later; the result is satisfaction or dissatisfaction with the use of the product [3]. Research on confirmation with satisfaction and continuation of IT products has been done before, such as [20]. They test web portal user satisfaction and report results that support the hypothesis significantly. Similarly, the results of research conducted by [28], confirmed the impact of user satisfaction and ongoing use of mobile internet.

Several previous studies linking confirmation with satisfaction with perceived usefulness [20], [28], [19], and perceived ease of use [28]. Perceived ease of use is a construct that measures the respondent's attitude or respondent's belief that a system is simple and not difficult in use. Results of previous studies on the use of SAP or ERP by the students showed a positive correlation between users' satisfaction [2], [1], [9], [17]. Likewise, studies using the Perceived Ease of Use as a mediating variable between independent variables with users' satisfaction giving significant results. Similarly, the perceived ease of use, perceived usefulness shows relevant results of the direct relation to the satisfaction or as mediation variable [2], [20], [28], [19], [9], [17]. Perceived usefulness is a variable that explaining user attitudes or beliefs that by utilizing a system will enhance their job's performance.

Previous studies that specifically examined the satisfaction from the context within the learning process were conducted by [16] and [17]. In these studies, student satis- 
faction was influenced by the learning process of the classroom, delivery of materials by the instructor. Furthermore, that the perceived ease of use also played a role as a mediating variable in the relationship between the student's satisfaction with the classroom and student's satisfaction with the instructor. Thus the research model can be formulated as in Figure 1.

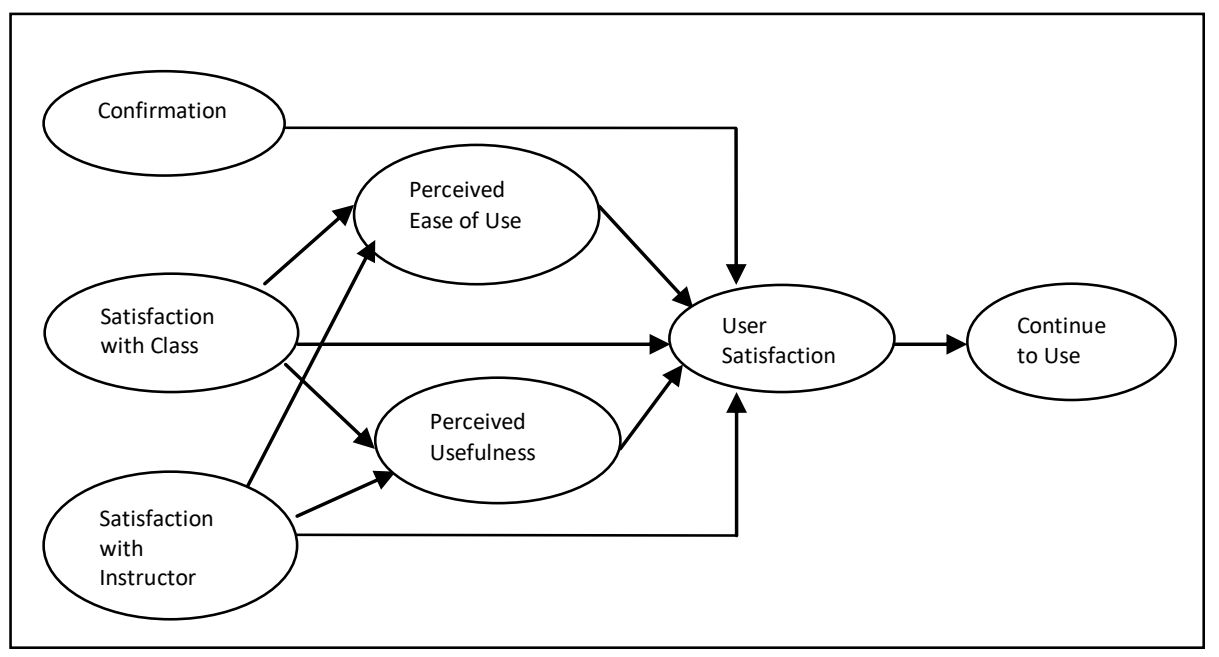

Fig. 1. Research Model

\section{Method}

This research is an explorative study that examines a student satisfaction model in using ERP system. The data deploy are primary data collected by survey using questionnaires distributed over the end of each training session. A questionnaire was distributed to 319 accounting students who had completed a course of SAP in 2014. The data collected were analyzed using Partial Least Square method of SEM models and processed using the program SmartPLS 2 (http://www.smartpls.com/). PLS is an alternative method of Structural Equation Modeling (SEM) analysis based on variance compared to the covarian-based SEM method represented by LISREL and Amos. SEM variance or often called Component Based SEM is represented by SmartPLS software, VisualPLS and PLS Graph. The main difference between Covariance Based SEM and Component Based SEM with PLS is on Partial Least Square Method (PLS) is used because conceptual model and measurement in this research is still in exploration stage of theory development. Basically PLS is very useful in analyzing and modeling minimum measurement scales and small sample sizes [32]; [33]. Using SEM concept, then data analysis is done in two stages of the testing outer model and inner model. The outer model test is performed to assess the validity and reliability of the data, while the inner model test is performed to obtain confirmation of the proposed model. 


\subsection{Variable and Measurement}

Confirmation: Confirmation refers to the students' attitude that gave statements or confirmation against what is expected related with the quality of SAP after the course compared to the students' perception before joining SAP courses. This variable is defined by four statements as follows:

- The SAP information was better than what I expected

- The quality of SAP was better than what I expected

- The service level provided by SAP was better than what I expected

- Overall, most of my expectations from using SAP were confirmed

Satisfaction with class: Satisfaction with the SAP class is a variable that measures the level of students' satisfaction with the course of SAP [16], which consists of the following four statements:

- SAP Class provides a satisfying learning experience

- SAP class is an interesting one

- SAP class does a good job of developing professional

- SAP class is more satisfying than most other classes

Satisfaction with instructor: Satisfaction with the instructor is to measure the level of students' satisfaction toward learning process within the classroom SAP [16], which consists of the following four statements:

- I am satisfied with the amount of guidance I receive

- I am satisfied with the help I receive from the SAP Class

- I am satisfied with the quality of instruction I receive

- My instructor provides satisfactory feedback

Perceived Ease of Use: Perceived ease of use is a variable that measures students' perception related to the ease of use with the device after the course of SAP, which consists of the following four statements:

- Learning to use SAP is easy to me

- My interactions with SAP would be clear and understandable

- It would be easy for me to become skillful in using SAP

- I would find SAP flexible to interact with

Perceived Usefulness: Perceived usefulness is a variable that measures students' perception regarding the benefits of the SAP after the course of SAP, which is composed of the following seven statements:

- SAP has an impact on my work in the future

- The SAP is useful for my work in the future

- Using SAP would improve my job performance

- Using SAP in my job would increase my productivity

- Using SAP would enhance my effectiveness on the job 
- Using SAP would make it easier to do my job.

- I would find SAP useful in my job.

Satisfaction: Satisfaction is a variable that measures students' satisfaction after learning SAP, consisting of the following six statements.

After using SAP I feel:

- Very satisfied

- Very pleased

- Very contented

- Absolutely delighted

- I feel satisfied when I decided to learn SAP

- I think my decision to learn SAP is correct

Continued SAP usage intention: SAP continued usage intention is a variable that measures students' opinion related to his or her desire to keep using SAP in the future, which consists of the following four statements:

- I intend to find a job related to SAP

- I intend to learn more about SAP

- I intend to continue using SAP in the future

- I hope the usage of SAP will continue in the future

The whole question's item will be measured using a 5-point Likert scale where 1 is for strongly disagrees and 5 for strongly agree.

\section{$4 \quad$ Result and Discussion}

The respondents were 319 students that attended the course of SAP during 2014, but data returned as much as 293 copies. Of the 293 respondents who participated in the survey, there were 97 males and 196 female students. Most participants were in the range of age 21-22 years old, and only 113 students had the experience of using the accounting software, i.e., MYOB (103) and ACCURATE (10), while most participants stated that they had no experience of using the accounting software.

Table 1. Respondent Profile

\begin{tabular}{|l|l|l|}
\hline \multicolumn{1}{|c|}{ Gender } & \multicolumn{1}{c|}{ Frequency } & \multicolumn{1}{c|}{ Percentage } \\
\hline Male & 97 & $33 \%$ \\
\hline Female & 196 & $67 \%$ \\
\hline Age & & \\
\hline $19-20$ years old & 39 & $13 \%$ \\
\hline $21-22$ years old & 170 & $58 \%$ \\
\hline $23-24$ years old & 70 & $24 \%$ \\
\hline$>25$ years old & 14 & $5 \%$ \\
\hline Accounting Software Experience & \multicolumn{2}{|l|}{} \\
\hline MYOB & 103 & $35 \%$ \\
\hline ACCURATE & 10 & $3 \%$ \\
\hline Never & 180 & $61 \%$ \\
\hline
\end{tabular}




\subsection{Testing Model}

The model of the research was tested using the PLS with the help of the SmartPLS 2 programs. Testing was conducted in two phases, namely:

Measurement Model (Outer Model): The first is to test the validity of measurements using convergent validity by looking at the loading factor value. Convergent validity is a measure that tests the validity for the measurement model with a reflective indicator. This value indicates the correlation between the indicators of the latent variable. This means that the higher the value of the convergent validity, the higher the indicator relationships with its latent variable. The acceptable value for convergent validity is $0.5-0.6$ while convergence validity values above 0.7 are considered very high. The result of preliminary analysis using SmartPLS 2 shows that the overall indicator has a factor loading value above 0.6 , unless there are two indicators for the satisfaction variable showing a value less than 0.5 so both indicators are excluded from the model. Further results of analysis yielded values for the entire indicator loading factor greater than 0.6 , and the value is higher than the value of cross loading on other latent variable blocks. Thus this model has a good convergent validity and discriminant validity.

The next is to see the value of composite reliability, as shown in Table 2. The model has a value above 0.7 composite reliability and Average Variance Extracted (AVE) square root value greater than the value of the correlation between latent constructs (Table 3 ). It can be concluded that this model has a good reliability.

Table 2. Composite Reliability, AVE, and R Square

\begin{tabular}{|l|c|c|c|c|}
\hline & Composite Reliability & AVE & $\sqrt{\text { AVE }}$ & R Square \\
\hline CONF & 0.734 & 0.408 & 0.639 & \\
\hline CONT & 0.757 & 0.438 & 0.662 & 0.295 \\
\hline EUS & 0.797 & 0.495 & 0.703 & 0.551 \\
\hline PEOU & 0.832 & 0.554 & 0.744 & 0.268 \\
\hline PU & 0.832 & 0.453 & 0.673 & 0.205 \\
\hline SWC & 0.773 & 0.461 & 0.679 & \\
\hline SWI & 0.806 & 0.510 & 0.714 & \\
\hline
\end{tabular}

Table 3. Correlation between Latent construct with AVE Square root

\begin{tabular}{|l|l|l|l|l|l|l|l|}
\hline & CONF & CONT & EUS & PEOU & PU & SWC & SWI \\
\hline CONF & $\mathbf{0 . 6 3 9}$ & & & & & & \\
\hline CONT & 0.527 & $\mathbf{0 . 6 6 2}$ & & & & & \\
\hline EUS & 0.546 & 0.543 & $\mathbf{0 . 7 0 3}$ & & & & \\
\hline PEOU & 0.430 & 0.544 & 0.507 & $\mathbf{0 . 7 4 4}$ & & & \\
\hline PU & 0.484 & 0.525 & 0.414 & 0.341 & $\mathbf{0 . 6 7 3}$ & & \\
\hline SWC & 0.560 & 0.654 & 0.699 & 0.511 & 0.453 & $\mathbf{0 . 6 7 9}$ & \\
\hline SWI & 0.462 & 0.558 & 0.600 & 0.442 & 0.353 & 0.706 & $\mathbf{0 . 7 1 4}$ \\
\hline
\end{tabular}

Note: diagonal is AVE square root value

Structural Model (Inner Model): The second stage is to assess structural models through path coefficient value of the parameter estimates and the level of significance. As shown in Table 4, all relationships have a high significance value above 1.96 except the relationship PU with EUS and SWI with PU. This shows that the confirma- 
tion, perceived ease of use, satisfaction with class, and satisfaction with instructor affects student satisfaction. Then satisfaction with class and instructor affect the perceived ease of use, and then only satisfaction with class affects perceived usefulness. Finally, students' satisfaction affects students' intention to continue to use SAP in the future.

Table 4. Path Coefficient and T Statistics

\begin{tabular}{|l|c|c|c|}
\hline & Original Sample & Standard Deviation & T Statistics \\
\hline CONF -> EUS & 0.169 & 0.028 & 6.061 \\
\hline EUS -> CONT & 0.543 & 0.028 & 19.729 \\
\hline PEOU -> EUS & 0.152 & 0.026 & 5.977 \\
\hline PU -> EUS & 0.051 & 0.028 & 1.854 \\
\hline SWC -> EUS & 0.404 & 0.040 & 10.051 \\
\hline SWC -> PEOU & 0.412 & 0.050 & 8.312 \\
\hline SWC -> PU & 0.433 & 0.041 & 10.628 \\
\hline SWI -> EUS & 0.130 & 0.033 & 3.945 \\
\hline SWI -> PEOU & 0.131 & 0.047 & 2.766 \\
\hline SWI -> PU & 0.026 & 0.042 & 0.620 \\
\hline
\end{tabular}

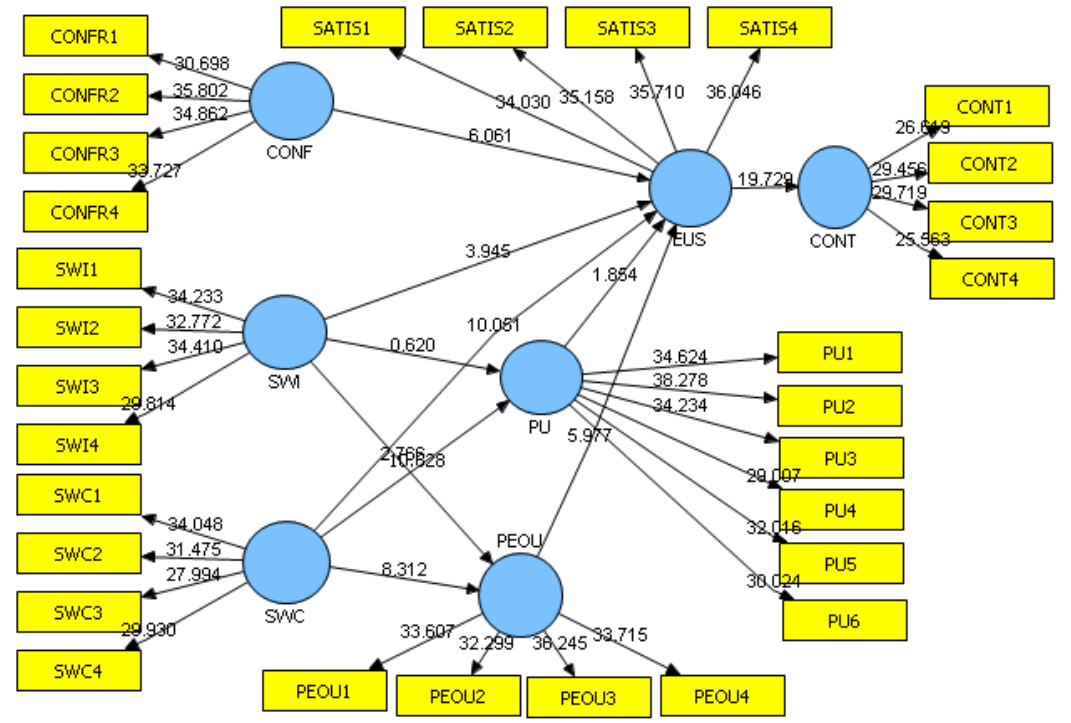

Fig. 2. Structural Model

\subsection{Discussion}

The results of analysis using SmartPLS 2 showed that the model had a good validity and reliability (see Figure 2 Structural Model). Based on the structural models, it can be concluded that the proposed research model remained relevant in measuring user satisfaction system using TAM and ECT [28]. However, perceived usefulness variables appear to be insufficient evidence of user satisfaction, which is consistent 
with previous studies [20], [1], but in contrast with the results of research [9], [2]. Furthermore, that in this study, variable perceived usefulness is not proven in support of satisfaction, this provides an opportunity for further training process to inform participants about the importance of ERP mastery on the job, especially when they later work on companies that have used ERP.

Next, the confirmation of expectations of student related with the quality of SAP after the course affected students' satisfaction through the use of the SAP. This is because students had a good experience, i.e., the course exceeded earlier students' expectations about the SAP program. A delightful experience of classroom courses and delivery the course materials by the instructor also contributed to students' satisfaction in using the SAP program. This shows that student satisfaction is influenced by the quality of the delivery process of the class materials [7]. Therefore, it can be concluded that the class situation and the satisfactory supply of materials by instructors provide strong support to shape students' perceptions about the quality and ease of use of SAP. Given that the training model is an intensive activity, this result is consistent with previous research that a comprehensive learning process within the classroom will improve students' understanding through the use of ERP [18], [25].

\section{Conclusion}

The increasing need for skilled labor in the field of ERP related to the escalates in user companies has been pursued by collaboration between vendors and universities in training for students. This study specifically formulated a model of student satisfaction in using ERP. Using a combination of TAM and ECT models, the analytical results provide support for the proposed model except for perceived usefulness. TAM and ECT models proposed are pertinent in assessing student's continuance in using the system in the future. Having a pleasant experience in the classroom and the satisfaction from the use of SAP encourage students to find a job that is interrelated to the use of SAP in the workplace.

This study examined the relationship between students' satisfaction with the class and the instructor following the instrument proposed by [16]. It should be noted that this instrument only assessed what students said about the class or instructor in general, not specifically about the learning method. Future studies may add the variable related to the learning method in conjunction with the results achieved by the participants during the course in order to present a more comprehensive picture of the model acceptance during SAP. In addition, to enrich the user satisfaction model of ERP system by students or prospective users through a training activity, further research needs to explore the motivation, expectation, and confirmation of the satisfaction of using ERP. The inherent limitations of using PLS as an analytical tool have limitations in terms of inability to generalize. These results are model predictions in testing student satisfaction in the learning process. Future models can still be tested to gain empirical evidence that students' satisfaction and success are related to their satisfaction with the classroom situation and the instructor. In addition, by increasing the 
number of test samples can be done using a covariance based Structural Equation Model represented by LISREL or Amos.

\section{References}

[1] Al-Jabri, Ibrahim, M., and Al-Hadab, A. "End User Adoption of ERP Systems: Investigation of Four Beliefs," In Proc. AMCIS 2008 Proceedings, Paper 104. Available: http://aisel.aisnet.org/amcis2008/104/. [Access March, 12, 2013]

[2] Amoako-Gyampah, K., and Salam, A. F. "An extension of the technology acceptance model in an ERP implementation environment," Information \& Management, vol. 41, no. 6, p. 731-745, October 2003. Available: https://pdfs.semanticscholar.org/ 6958/dff87758c01cd931 ea5bf00c0dad2f732bb8.pdf. Access March, 12, 2013] https://doi.org/10.1016/j.im.2003.08.010

[3] Bhattacherjee, A. "Understanding information systems continuance: an expectationconfirmation model," MIS quarterly, vol. 25, no. 23, p. 351-370, Sep 2001. Available: JSTOR, http://www.jstor.org/stable/3250921?seq=1\#page scan tab contents/. [Accessed March 12, 2013].

[4] Boudreau, M, "Learning to Use ERP Technology: A Causal Model," In Proc. 36th Annual Hawaii International Conference on System Sciences, (HICSS'03), 8, p. 235-244. Hawaii: 36th Annual Hawaii International Conference on System Sciences, January, 2003. Availablehttp://citeseerx.ist.psu.edu/viewdoc/download?doi=10.1.1.103.5524\&rep=rep1\&type $=p$ df. [Accessed March 13, 2013] https://doi.org/10.1109/HICSS.2003.1174611

[5] Cronan, T. P., and Douglas, D. E, "A student ERP simulation game: A longitudinal study," Journal of Computer Information Systems, vol. 53, no. 1, p. 3-13. 2012. Available: https://search.proquest.com/docview/1231586914. [Accessed March 13, 2013]

[6] Davis, F. D, "A technology acceptance model for empirically testing new end-user information systems: Theory and results," Doctoral dissertation, Massachusetts Institute of Technology, 1985.

[7] Encabo, H. C, "Canonical correlation analysis of student perception on instructional quality and satisfaction,” JPAIR Multidisciplinary Journal, vol. 6, no. 1, p. 1-1, May, 2011. https://doi.org/10.7719/jpair.v6i1.132

[8] Evangelista, R., Guerrieri, P., and Meliciani, V, "The economic impact of digital technologies in Europe". Economics of Innovation and New Technology, vol. 23, no. 8, p. 802824, 2014. https://doi.org/10.1080/10438599.2014.918438

[9] Garaca, Z, "Factors Related To The Intended Use Of ERP Systems," Management, vol. 16, no. 2, p. 23-42, 2011.

[10] Guthrie, R. W., and Guthrie, R. A, "Integration of enterprise system software in the undergraduate curriculum," In Proc. ISECON 17, 2000.

[11] Hayen, R. A., and Andera, F. A, "Investigation of the integration of SAP enterprise software in business curricula," Issues in Information Systems, vol. 6, no. 1, p. 107-113, 2005.

[12] Hayen, R. L., and Holmes, M. C,'SAP Enterprise Software In Curriculum Integration," Issues in Information Systems, vol. 15, no. 1, p. 141-148, 2014(a).

[13] Hayen, R. L., and Holmes, M. C, "SAP Enterprise Software Learning Experience In China” In Proc. ASBBS Annual Conference. 21:1, p. 373-388, Las Vegas: ASBBS Annual Conference, 2014 (b). 
[14] Hayen, R., and Cappel, J, "Certification in Enterprise Software: An SAP R/3 University Alliance Program Experiment," Issues in Information Systems, vol. 2, no. 1, p. 132-138, 2001.

[15] Hejazi, S. S., Halpin, A. L., and Biggs, W. D, "Using SAP ERP technology to integrate the undergraduate business curriculum, Developments in Business Simulation and Experiential Learning, vol. 30, p. 122-125, 2003.

[16] Hermans, C. M., Haytko, D. L., and Mott-Stenerson, B, "Student satisfaction in webenhanced learning environments," Journal of instructional pedagogies, vol. 1, no. 1, p. 119, 2009.

[17] Kanthawongs, P.S. N. I. T. T. A. N. A and Kanthawongs, P. E. N. J. U. R. E. E, "Student Satisfaction in Web-based ERP-Simulated Learning Environment," in Proc. 9th WSEAS International Conference on Education and Educational Technology (EDU'10), 2010..

[18] Kirkham, K., and Seymour, L, "The value of teaching using a live ERP system with resource constraints," In Proc. World Conference on Computers in Education (WCCE), Cape Town, 2005.

[19] Lee, M. C, "Explaining and predicting users' continuance intention toward e-learning: An extension of the expectation-confirmation model," Computers \& Education, vol. 54, no. 2, p. 506-516, 2010. https://doi.org/10.1016/j.compedu.2009.09.002

[20] Lin, C. S., Wu, S., and Tsai, R. J., "Integrating perceived playfulness into expectationconfirmation model for web portal context," Information \& Management, vol. 42, no. 5, p. 683-693, 2005. https://doi.org/10.1016/j.im.2004.04.003

[21] McCann, D., and Mellema, H., "ERP in an Integrated Business Course: Student Reactions to In-Class Introduction of SAP R/3," Issues in Information Systems, vol. 10, no. 1, p. 171-175, 2009.

[22] O’Sullivan, J., "Validating Academic Training versus Organizational Training: An Analysis in the Enterprise Resource Planning (ERP) Field," Journal of Communication and Computer, vol. 10, p. 1261-1270, 2013.

[23] Pantea, S., Biagi, F., and Sabadash, A, “Are ICT displacing workers? Evidence from seven European countries 2014. [Online].Available: https://papers.ssrn.com/sol3/pape rs.cfm?abstract id=2591076. [Accessed October, 14, 2015]

[24] Ravesteyn, P., and Kohler, A, "Industry Participation in Educating Enterprise Resource Planning," Communications of the IIMA, vol. 9, no. 2, p. 45-56, 2009.

[25] Reinicke, B. J.,'Implementing an integrated curriculum with an iterative process to support a capstone course in information systems," In Proc. the Information Systems Educators Conference IS, Vol. 2167, p. 1435, 2012.

[26] Sarreal, E. R., "Customer Satisfaction and Service Quality in a High-Contact Service Firm", DLSU Business \& Economics Review, vol. 17, no. 1, p. 1-12, 2008. https://doi.org/10.3860/ber.v17i1.32

[27] Strong, D., Fedorowicz, J., Sager, J., Stewart, G., and Watson, E. E, "Teaching with enterprise systems," Communications of the Association for Information Systems, vol. 17, no. 1, p. 728-755, 2006. [Online]. Available: http://aisel.aisnet.org/cais/. [Accessed March 13, 2013].

[28] Thong, J. Y., Hong, S. J., and Tam, K. Y., "The effects of post-adoption beliefs on the expectation-confirmation model for information technology continuance," International Journal of Human-Computer Studies, vol. 64, no. 9, p. 799-810, 2006. https://doi.org/10.1016/j.ijhcs.2006.05.001

[29] Vluggen, M., and Bollen, L., "Teaching enterprise resource planning in a business curriculum," International. Journal Information and Operations Management Education, vol. 1, no. 1, p. 44-57, 2005. https://doi.org/10.1504/IJIOME.2005.007447 
Paper-Student Satisfaction and Continuance Model of Enterprise Resource Planning (ERP) ...

[30] Wang, M., "Teaching Business Processes Integration with ERP In Enterprise Architecture/Systems Courses" International Journal of Computer and Communication Engineering, vol. 1, no. 4, p. 354-357, November, 2012. https://doi.org/10.7763/IJCCE.2012.V1.89

[31] Vluggen, M., and Bollen, L., "Teaching enterprise resource planning in a business curriculum," Int. J. Information and Operations Management Education, vol. 1, no. 1, p. 44-57, March, 2005. https://doi.org/10.1504/IJIOME.2005.007447

[32] Henseler, J., Ringle, C. M., and Sinkovics, R. R, "The use of partial least squares path modeling in international marketing". In New challenges to international marketing, p. 277-319, 2009. Emerald Group Publishing Limited.

[33] Ainuddin, R. A., Beamish, P. W., Hulland, J. S., and Rouse, M. J., "Resource attributes and firm performance in international joint ventures" Journal of World Business, Vol 42, no. 1, p. 47-60, 2007. https://doi.org/10.1016/j.jwb.2006.11.001

\section{$7 \quad$ Authors}

Weli, Universitas Katolik Indonesia Atma Jaya Jakarta-Indonesia. Economics and Business Faculty, Accounting Department, Jalan Jendral Sudirman Kav 51, Jakarta 12930. E-mail:weli.imbiri@gmail.com

Article submitted 30 March 2018. Resubmitted 27 April 2018. Final acceptance 13 August 2018. Final version published as submitted by the author. 